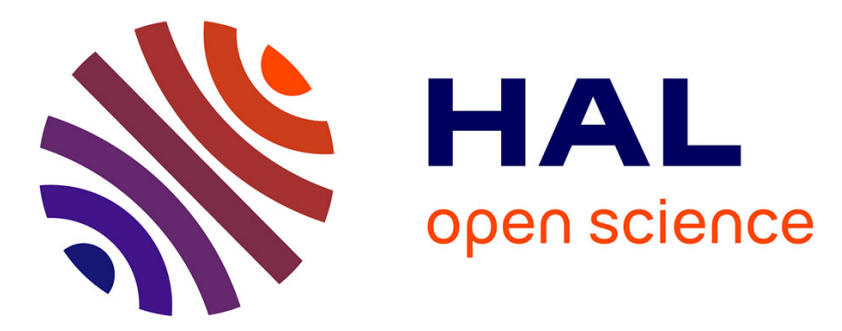

\title{
Protein interaction with SiO2 and AgNPs: from adsorption on solid surfaces to organization and conformational changes
}

Marvine Soumbo, Christina Villeneuve-Faure, Caroline Bonafos, Christine Roques, Kremena Makasheva

\section{To cite this version:}

Marvine Soumbo, Christina Villeneuve-Faure, Caroline Bonafos, Christine Roques, Kremena Makasheva. Protein interaction with $\mathrm{SiO} 2$ and AgNPs: from adsorption on solid surfaces to organization and conformational changes. 2021 IEEE 16th Nanotechnology Materials and Devices Conference (NMDC), Dec 2021, Vancouver, Canada. pp.1-4, 10.1109/NMDC50713.2021.9677562 . hal-03578945

\section{HAL Id: hal-03578945 \\ https://hal.science/hal-03578945}

Submitted on 17 Feb 2022

HAL is a multi-disciplinary open access archive for the deposit and dissemination of scientific research documents, whether they are published or not. The documents may come from teaching and research institutions in France or abroad, or from public or private research centers.
L'archive ouverte pluridisciplinaire $\mathbf{H A L}$, est destinée au dépôt et à la diffusion de documents scientifiques de niveau recherche, publiés ou non, émanant des établissements d'enseignement et de recherche français ou étrangers, des laboratoires publics ou privés. 


\section{Protein interaction with $\mathrm{SiO}_{2}$ and AgNPs: from adsorption on solid surfaces to organization and conformational changes}

\author{
Marvine Soumbo \\ LAPLACE, Université de Toulouse, \\ CNRS, UPS, INPT, Toulouse, France \\ LGC, Université de Toulouse, CNRS, \\ UPS, INPT, Toulouse, France \\ soumbo@laplace.univ-tlse.fr \\ Christine Roques \\ LGC, Université de Toulouse, CNRS, \\ UPS, INPT, Toulouse, France \\ ch.roques@wanadoo.fr
}

\author{
Christina Villeneuve-Faure \\ LAPLACE, Université de Toulouse, \\ CNRS, UPS, INPT, Toulouse, France \\ villeneuve@laplace.univ-tlse.fr
}

\author{
Kremena Makasheva \\ LAPLACE, Université de Toulouse, \\ CNRS, UPS, INPT, Toulouse, France \\ makasheva@laplace.univ-tlse.fr
}

\author{
Caroline Bonafos \\ CEMES-CNRS, Université de Toulouse, \\ Toulouse, France \\ bonafos@cemes.fr
}

\begin{abstract}
Driven by many applications, the development of new biomaterials has considerably increased in the last decade. The current research strategies also involve revealing of the relationship between protein structure and function due to the exposure and interaction of proteins with non-biological organic and inorganic solid surfaces. Aiming at understanding of the mechanisms of protein adsorption on solid surfaces we follow in this work the organization dynamics of proteins (Bovine Serum Albumin, BSA and Fibronectin, Fn) adsorbed on thin silica layers without or with silver nanoparticles (AgNPs), deposited on their surfaces. It is found that although starting with the same protein concentration in solution $(0.05 \mathrm{~g} / \mathrm{L})$, the adsorbed amount of proteins on $\mathrm{SiO}_{2}$ surfaces is twice larger for $\mathrm{Fn}$ $\left(1.32 \mu \mathrm{g} / \mathrm{cm}^{2}\right)$ compared to BSA $\left(0.58 \mu \mathrm{g} / \mathrm{cm}^{2}\right)$. The proteins adopt different conformations according to the surface pattern. On a flat $\mathrm{SiO}_{2}$ surface, the $\mathrm{BSA}$ proteins organize in a lace-like network while the Fn proteins adopt a branching-type. The patterned by AgNPs surfaces induce conformational changes of the proteins. In interaction with AgNPs both types of proteins fold up to attain mainly compact globular conformation.
\end{abstract}

Keywords-AgNPs, $\mathrm{SiO}_{2}$, proteins, adsorption, conformation

\section{INTRODUCTION}

Recent advances in biotechnology related to development of biosensors, photosensitizers, artificial implants, bioelectronics, etc. require addressing, among others, the "protein-adsorption problem" on solid surfaces and incite studies on the underlying physico-chemical mechanisms of their interaction. Proteins represent an important class of biomolecules [1]. Whenever a material (device) is brought to a contact with a physiological fluid one of the first events to occur is adsorption of the freely available in the fluid proteins on the material surface [2-5]. The adsorption of a specific protein on the material surface is strongly affected by the presence of other proteins in the solution and by those already adsorbed on the material since according to the adopted conformation, the adsorbed proteins may expose new binding sites for subsequent protein-protein interactions. By adopting different conformations, the adsorbed proteins condition the surface, determine the biological response of the material and control further biological processes [6,7]. Thus, in a bigger picture, the protein adsorption on solid surfaces represents the stage of conditioning of the surface, for example, for adhesion of microorganisms [8]. Microbial adhesion and subsequent biofilm formation are at the origin of hospital-acquired infections, often leading to septic complications and lethal issues [9]. This Public Health problem is at the core of actuality more than ever due to the emergence and selection of antibiotic-resistant bacteria which strongly limits the currently existing methods of treatment [10]. Accordingly, all related studies are timely actions. In line with this strategy we focus on the adsorption of proteins on solid surfaces. We investigate the interaction of proteins with solid surfaces of $\mathrm{SiO}_{2}$ thin layers and with silver nanoparticles (AgNPs) deposited on the surface of $\mathrm{SiO}_{2}$. Working with thin layers is related to creation of antimicrobial coatings. Silver, and particularly AgNPs, exhibits inherent antimicrobial properties. In the last decade, the antimicrobial activity of AgNPs has led to an extensive research of the involved molecular mechanisms, aiming at a broad application of silver-containing materials in the biomedical domain. It is well known now that the extreme biological activity of AgNPs is closely related to the released amount of ionic $\mathrm{Ag}\left(\mathrm{Ag}^{+}\right)$or to a direct contact of the microorganisms with AgNPs, resulting in protein denaturation at different cell locations [11-16]. The approaching to the surface microorganisms do not have specific receptors to bind the material. Actually, the already adsorbed on the surface proteins act as interface between the microorganisms and the material [8]. This complex and time-evolving system requires a close study of the interaction of proteins with silica surfaces and with silver species. The current contribution addresses adsorption, organization and conformational changes of two globular proteins, namely Bovine Serum Albumin (BSA) and Fibronectin (Fn) on thin silica layers without and with AgNPs, aiming at to assess their respective contributions.

\section{EXPERIMENTAL PART}

\section{A. Substrate elaboration}

The silica $\left(\mathrm{SiO}_{2}\right)$ layers were thermally grown on intrinsic Si-substrates at $1100^{\circ} \mathrm{C}$ under slightly oxidizing atmosphere, using a $\mathrm{N}_{2}-\mathrm{O}_{2}$ gas mixture with $1.0 \%$ of $\mathrm{O}_{2}$. Before being exposed to proteins, the $\mathrm{SiO}_{2} / \mathrm{Si}$ substrates were consecutively cleaned in ethanol (95\% vol.) and acetone (95\% vol.) and then rinsed in deionized water until obtaining zero conductivity to avoid electrostatic interactions on the sample surfaces. 
The same $\mathrm{SiO}_{2}$ thin layers were used to deposit a single plane of AgNPs on their surfaces. The AgNPs were obtained by Ag-sputtering for $5 \mathrm{~s}$ in an Ar-discharge (a radio-frequency capacitively-coupled plasma with an axial asymmetry of the electrodes) maintained at a pressure $\mathrm{p}_{\mathrm{Ar}}=5.4 \mathrm{~Pa}$ with a power $\mathrm{P}=80 \mathrm{~W}$ (self-bias voltage of the powered electrode $\mathrm{V}_{\mathrm{dc}}=-950 \mathrm{~V}$ ). More details on the plasma process and the deposition procedure can be found elsewhere [17, 18].

\section{B. Proteins}

Two globular proteins, namely BSA and Fn, were selected for this study. BSA has been chosen as a model protein and the choice of Fn was based on the large implication of this protein, as intermediate, in microbial adhesion. BSA and Fn were purchased from Sigma Aldrich. According to their SDSPAGEs, the BSA was at least $96 \%$ pure and the Fn was at least $85 \%$ pure. Both proteins were in a lyophilized powder form.

Stock solutions of BSA and Fn were prepared with a concentration of $5.0 \mathrm{~g} / \mathrm{L}$ in $50 \mathrm{ml}$ water for injections (WFI water, European Pharmacopoeia, COOPER) with $\mathrm{pH}$-value measured to 7.0 and conductivity of $1.2 \mu \mathrm{S} / \mathrm{cm}$. Aliquots of the BSA and the Fn stock solutions were then diluted 2-100 times in WFI water. The measured $\mathrm{pH}$-value of the stock solution was 5.6 for BSA and 7.5 for Fn. The assays were performed at room temperature $\left(23^{\circ} \mathrm{C}\right)$.

The proteins were deposited on the silica surfaces and on the AgNPs by dip coating process [19]. The substrates were immersed for 1 hour in $1 \mathrm{~mL}$ of the protein solution to achieve protein adsorption. After the immersion step, the samples were rinsed in WFI water to remove all non-adhered proteins and were left dehydrating at room temperature and atmospheric pressure before characterization of the interaction of proteins with the selected surfaces.

\section{Characterization methods}

The $\mathrm{SiO}_{2}$ thin layers, the AgNPs-patterned $\mathrm{SiO}_{2}$ substrates and the adsorbed proteins were studied by Scanning Electron Microscopy (SEM), spectroscopic ellipsometry (SE) and Atomic Force Microscopy (AFM). A JEOL JSM 7800F Prime-EDS microscope was used to evaluate the obtained AgNPs and the adsorbed proteins. A Semilab ellipsometer SE2000 with a rotating polarizer and a fixed analyzer was used in the spectral range $250-850 \mathrm{~nm}$ for the SE measurements. Bruggeman model was applied to extract the thickness and optical properties (refractive index, $\mathrm{n}$ and extinction coefficient, k) of the $\mathrm{SiO}_{2}$ layers. Cauchy dispersion law was applied for interpretation of the recorded spectra of adsorbed proteins, since the two studied proteins are optically nonabsorbing [19]. The protein surface concentration, i.e. the adsorbed protein mass per unit area, was obtained using the refractive indexes, after applying the de Feijter's expression [20]. AFM topography images were acquired with a Bruker Multimode 8 set-up using Peak-Force Quantitative NanoMechanical (PF-QNM) mode. To probe proteins a SNL tip with spring constant of $0.42 \mathrm{~N} / \mathrm{m}$ and curvature radius of around $5 \mathrm{~nm}$ was used. The peak force was set to $0.5 \mathrm{nN}$.

\section{RESULTS AND DISCUSSION}

\section{A. Structural analysis of the synthesized $\mathrm{SiO}_{2}$ thin layers and $\mathrm{AgNPs}$ deposited on $\mathrm{SiO}_{2}$}

The SE analysis of the thermally grown silica shows a high quality of the obtained thin $\mathrm{SiO}_{2}$ layers. Their refractive index is $\mathrm{n}=1.45$, at $\lambda=632.8 \mathrm{~nm}$. They are transparent. The extinction coefficient is $\mathrm{k}=0$ in the entire spectral range. The layer thickness is $84.4 \mathrm{~nm}$. The same $\mathrm{SiO}_{2}$ layers were used as substrates for the plasma deposition of AgNPs. SEM images (Figure 1(a)) of the AgNPs show that they are organized in a monolayer and are homogeneously distributed on the $\mathrm{SiO}_{2}$ surface, covering $51 \%$ of it. Their shape can be defined as prolate spheroid. The AgNPs are positioned on the surface with random orientation of their major axis. They are well isolated from each other. As shown in Figure 1(b), the AgNPs are of size $19.7 \pm 7.6 \mathrm{~nm}$ and follow a Gaussian distribution.
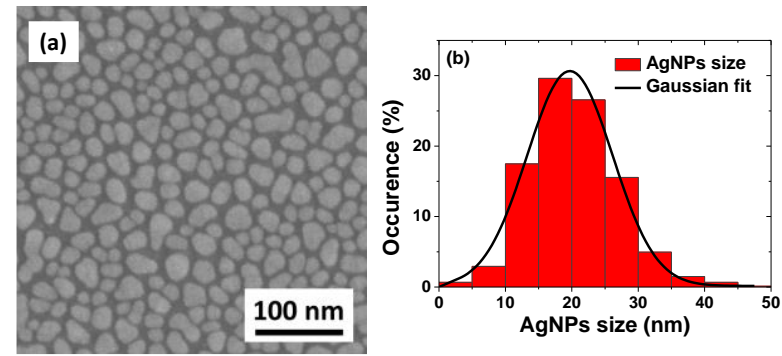

Fig. 1. (a) SEM image of the plasma synthesized $\mathrm{AgNPs}$ on $\mathrm{SiO}_{2}$ thin layers and (b) statistical analysis made on more than 1000 AgNPs.

\section{B. Adsorption and organisational dynamic of BSA and Fn on the surface of $\mathrm{SiO}_{2}$ thin layers}

The adsorption and organization of BSA $(0.05 \mathrm{~g} / \mathrm{L}$ in solution with WFI water) on the $\mathrm{SiO}_{2}$ surface is presented in Figure 2, where Figure 2(a) shows the 3D-structure of BSA and indicates the protein size. The selected protein concentration is consistent with typical protein concentrations found in blood samples. Analysis of the SE spectra (Figure 2(b)) of the adsorbed proteins gives a protein monolayer with thickness of $4.1 \pm 0.1 \mathrm{~nm}$ and refractive index of $n_{\mathrm{p}-\mathrm{BSA}}=1.61$. After applying the de Feijter expression one
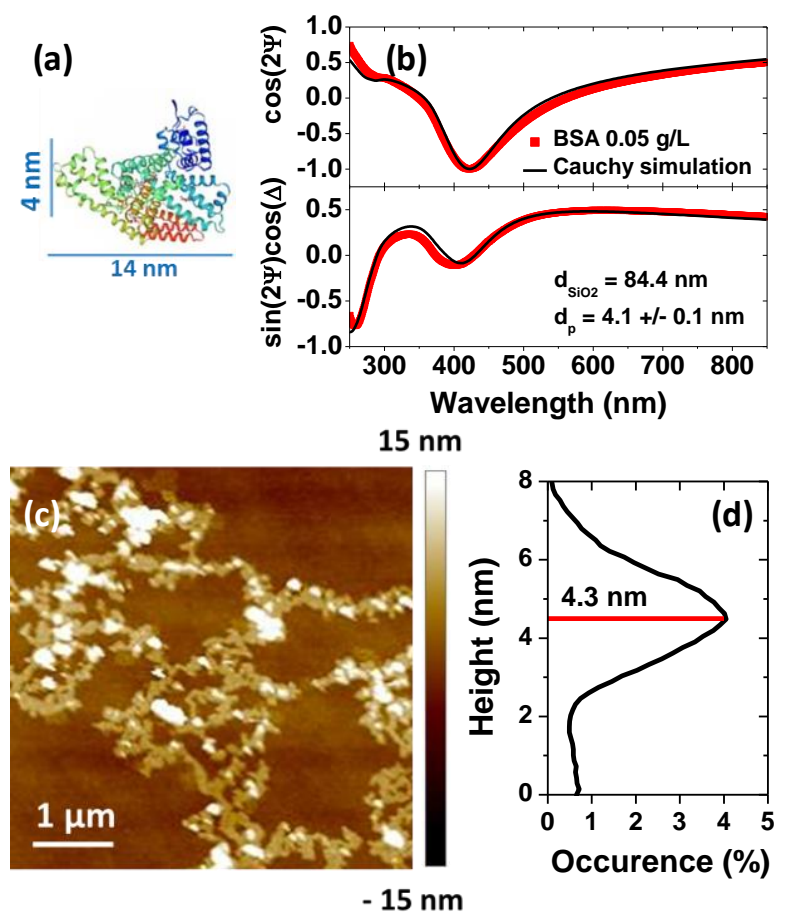

Fig. 2. Adsorption of BSA (from solution with concentration of $0.05 \mathrm{~g} / \mathrm{L}$ ) on $\mathrm{SiO}_{2}$ surfaces: (a) representation of the 3D-structure of BSA, (b) Ellipsometric spectra of the adsorbed BSA, (c) PF-QNM AFM image of the protein organization and (d) height histogram of the adsorbed BSA. 
finds a surface concentration of BSA $\Gamma_{\mathrm{BSA}}=0.58 \mu \mathrm{g} / \mathrm{cm}^{2}$. According to the AFM topography (Figure 2(c)) the adsorbed BSA is organized in a lace-like network on the surface. The height histogram resulting from PF-QNM analysis (Figure 2(d)) shows a single peak with value of $4.3 \mathrm{~nm}$ between the protein and the $\mathrm{SiO}_{2}$ substrate. It means that for this small BSA concentration the resulting layer is noncontinuous and the proteins are 'side-on' adsorbed on the surface. The obtained value is consistent with the BSA smaller dimension (minor axis of the spheroid, Figure 2(a)). It also perfectly correlates with the thickness of protein layer found from the SE analysis.
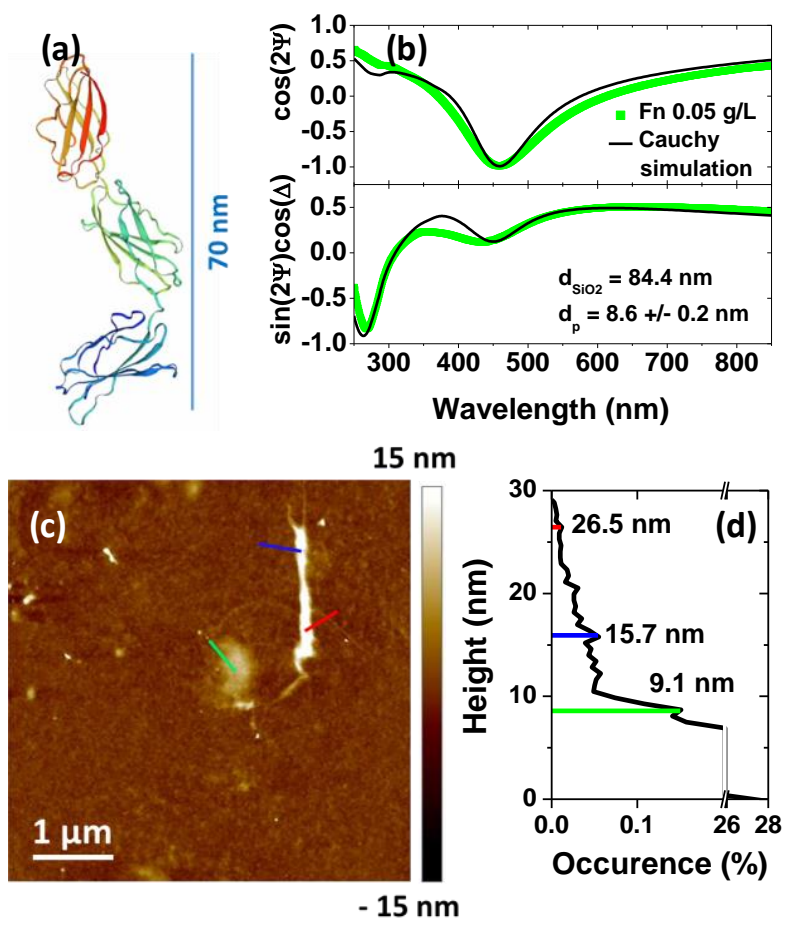

Fig. 3. Adsorption of Fn (from solution with concentration of $0.05 \mathrm{~g} / \mathrm{L}$ ) on $\mathrm{SiO}_{2}$ surfaces: (a) representation of the 3D-structure of $\mathrm{Fn}$, (b) Ellipsometric spectra of the adsorbed Fn, (c) PF-QNM AFM image of the protein organization, (d) height histogram of the adsorbed Fn.

Similar analysis was conducted for the resulting protein layers from Fn solution $(0.05 \mathrm{~g} / \mathrm{L}$ in solution with WFI water) (Figure 3). Fn proteins organize on the silica surface in a very different way compared to the BSA, due to structural differences and their much larger size $(2 \times 70 \mathrm{~nm}$, Figure 3(a)). The obtained from SE protein layer thickness is of $8.6 \pm 0.2 \mathrm{~nm}$ (Figure 3(b)). The extracted refractive index is $\mathrm{n}_{\mathrm{p}-\mathrm{Fn}}=1.62$, giving a surface concentration of $\Gamma_{\mathrm{Fn}}=1.32 \mu \mathrm{g} / \mathrm{cm}^{2}$. It is worth pointing out that one achieves twice larger surface concentration for Fn, compared to BSA, although starting with solutions with the same concentration.

The AFM topography study shows that in interaction with the $\mathrm{SiO}_{2}$ surface, the Fn either fold up to achieve a globular shape or adopt more complex branch-type structures as shown in Figure 3(c). This is represented on the height histogram in Figure 3(d), where three characteristic heights can be observed. They are consistent with different Fn conformations. The most frequently occurring height is of $9.1 \mathrm{~nm}$, which correlates well with the hydrodynamic radius of Fn in aqueous solution (8.7 nm [21]), and suggests globular compact conformation. The two other specific heights are of $15.7 \mathrm{~nm}$ and $26.5 \mathrm{~nm}$. They can be assigned to partially unfolded and elongated protein conformations. It appears that the three conformational models for protein: globular (folded compact), branched, or linear (extended), can be assumed for the Fn after adsorption and dehydration on the silica surfaces.

The above analysis is confirmed by studies on adsorbed proteins from higher Fn concentrations. Figure 4 shows that the adsorbed proteins from solution with protein concentration of $1 \mathrm{~g} / \mathrm{L}$ in WFI water organize in a fractal-type structure with nodes much higher that $300 \mathrm{~nm}$ and branches with average height of only $40 \mathrm{~nm}$. It approves that other protein models, like complex random or looped ones also exist. These results validate the trend of Fn to adopt different conformations in interaction with $\mathrm{SiO}_{2}$ solid surfaces.

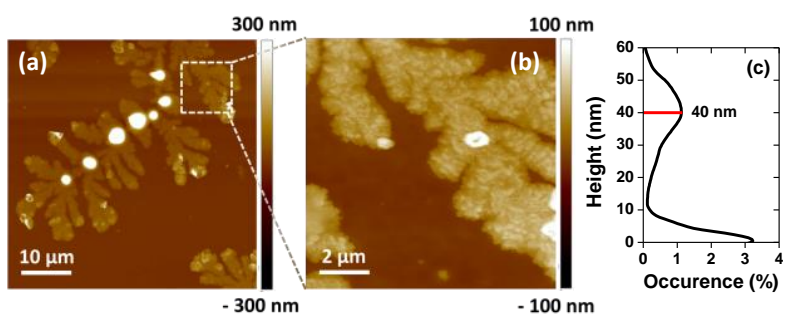

Fig. 4. PF-QNM AFM images of the organization of Fn (from $1 \mathrm{~g} / \mathrm{L}$ in solution) on $\mathrm{SiO}_{2}$ surfaces: (a) $50 \times 50 \mu \mathrm{m}$ and (b) zoom in the upper right part $5 \times 5 \mu \mathrm{m}$ and (c) the corresponding height histogram.

\section{Interaction of BSA and Fn with AgNPs-patterned $\mathrm{SiO}_{2}$ surfaces}

The protein adsorption changes radically when the $\mathrm{SiO}_{2}$ surface is patterned with AgNPs. On the other hand, in interaction with the AgNPs, the adsorbed proteins alter the release of the very reactive $\mathrm{Ag}^{+}$ion, by enhancing or depressing its amount [22]. Figure 5 shows the interaction of BSA $(0.05 \mathrm{~g} / \mathrm{L}$ in solution with WFI water $)$ with the patterned by $\mathrm{AgNPs} \mathrm{SiO}_{2}$ surface. For this protein concentration one observes that BSA proteins organize in small islands encompassing the AgNPs in a region of around $100 \mathrm{~nm}$ in diameter. The islands are positioned at distances of at least $500 \mathrm{~nm}$ from each other (Figure 5(a)). A closer look (Figure 5(c)) suggests that the AgNPs are captured by the BSA proteins forming the so-called "protein corona". A consideration based only on electrostatic interaction cannot explain this globular compact conformation, since BSA (isoelectric point, $\mathrm{pI}=4.7$ ) and the surface of AgNPs both are negatively charged in the solution $(\mathrm{pH}=5.6)$. Most likely the strong binding of BSA on the AgNPs is supported by sulfursilver complexes, since BSA contains 583 amino acid residues and has 17 cysteine residues ( 8 disulfides bridges and 1 free thiol group) [23].
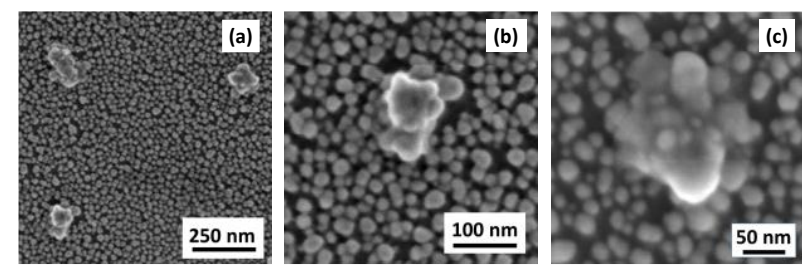

Fig. 5. SEM images showing deposition of BSA from a solution with concentration of $0.05 \mathrm{~g} / \mathrm{L}$ on AgNPs.

The Fn has similar behaviour in interaction with the AgNPs (Figure 6). Again the globular compact conformation is observed, with islands positioned at distance of $500 \mathrm{~nm}$. However, one can see (Figure 6(b)) that the Fn adopts also 
unfolded and elongated protein conformations. Due to the much larger size of Fn, the region of interaction with the AgNPs is 3 times the protein size, i.e. around $400 \mathrm{~nm}$ in diameter (Figure 6(c)). Similarly, electrostatic interaction with the AgNPs is unlikely since the Fn (isoelectric point $\mathrm{pI}=5.5-6.0)$ and the AgNPs are negatively charged in the solution $(\mathrm{pH}=7.5)$. Again the thiol groups are in charge of the strong binding of Fn to the AgNPs. Although the SH-groups of free Fn are buried from the protein surface, they become fully exposed upon adsorption to a surface [24].
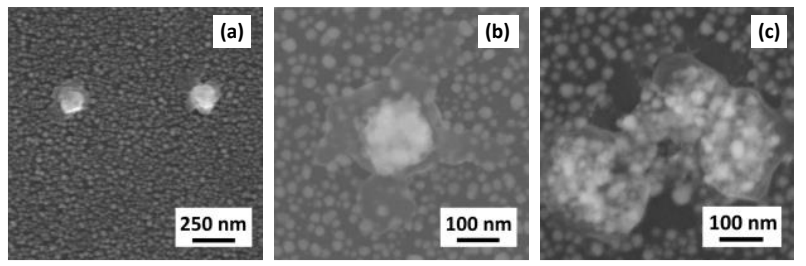

Fig. 6. SEM images showing deposition of Fn from a solution with concentration of $0.05 \mathrm{~g} / \mathrm{L}$ on AgNPs.

Increasing the Fn protein concentration to $1 \mathrm{~g} / \mathrm{L}$ does not seem to induce radical changes of the Fn adsorption on AgNPspatterned $\mathrm{SiO}_{2}$ layers (Figure 7). The globular compact type and the unfolded, and elongated protein conformations are preserved. However, the Fn organize mainly in a star-type shape, covering larger regions of $\operatorname{AgNPs}(3-5 \mu \mathrm{m})$.

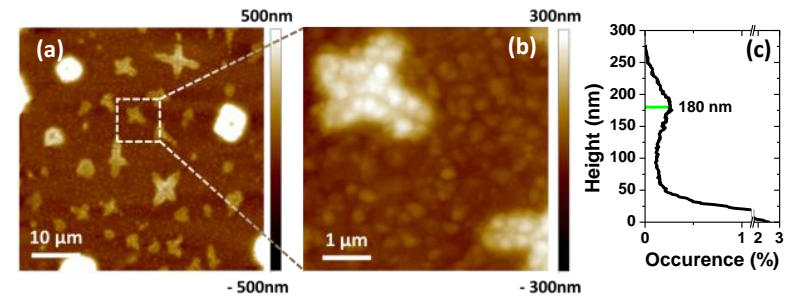

Fig. 7. PF-AFM images of the organization of Fn (from $1 \mathrm{~g} / \mathrm{L}$ in solution) on AgNPs: (a) $50 \times 50 \mu \mathrm{m}$ and (b) zoom in the central part $5 \times 5 \mu \mathrm{m}$ and (c) the corresponding height histogram.

\section{CONCLUSIONS}

Adsorption of BSA and Fn on $\mathrm{SiO}_{2}$ surfaces leads to a lace-like and branching type organization, respectively. Although starting with the same protein concentration in solution, the amount of adsorbed on the $\mathrm{SiO}_{2}$ surface proteins is systematically twice larger for Fn compared to BSA. Electrostatic interaction of both BSA and Fn with AgNPs is unlikely. The thiol groups are in charge of the strong binding of BSA and Fn to the AgNPs creating sulfur-silver complexes.

In the future we will study protein adsorption when the solution contains mixture of proteins. Such approach will answer questions related to protein-protein interactions and to protein dynamics driven by the Vroman effect. The protein adsorption on AgNPs surface is expected to be modified by the kinetic rates and by proper protein-AgNPs interaction.

\section{ACKNOWLEDGMENT}

The authors acknowledge support from the UAR Raymond Castaing of the University of Toulouse and Mr Stéphane Le Blond du Plouy for the SEM observations. Research supported by the program IDEX Transversalité of University of Toulouse (ANR-11-IDEX-0002-02), under project ADAGIO. M. S. acknowledges $\mathrm{PhD}$-grant from Université de Toulouse and Région Occitanie.

\section{REFERENCES}

[1] D. Whitford, Proteins: Structure and Function. John Wiley \& Sons Ltd., Chichester, England, 2005.

[2] C. J. Wilson, R. E. Clegg, D. I. Leavesley, and M. J. Pearcy, "Mediation of Biomaterial-Cell Interactions by Adsorbed Proteins: A Review," Tissue Eng., vol. 11, pp. 1-18, 2005.

[3] C. Werner, M. F. Maitz, and C. Sperling, "Current strategies towards hemocompatible coatings," J. Mater. Chem., vol. 17, p. 3376, 2007.

[4] P. Parhi, A. Golas, and E. A. Vogler, "Role of Proteins and Water in the Initial Attachment of Mammalian Cells to Biomedical Surfaces: A Review," J. Adhes. Sci. Technol., vol. 24, pp. 853-888, 2010.

[5] E. A. Vogler, "Protein adsorption in three dimensions," Biomaterials, vol. 33, pp. 1201-1237, 2012.

[6] P. Roach, D. Farrar, and C. C. Perry, "Interpretation of Protein Adsorption: Surface-Induced Conformational Changes," J. Am. Chem. Soc., vol. 127, pp. 8168-8173, 2005.

[7] J. Valencia-Serna, P. Chevallier, R. B. Kc, G. Laroche, and H. Uludağ, "Fibronectin-modified surfaces for evaluating the influence of cell adhesion on sensitivity of leukemic cells to siRNA nanoparticles," Nanomed., vol. 11, pp. 1123-1138, 2016.

[8] M. Soumbo, A. Scarangella, C. Villeneuve-Faure, C. Bonafos, C. Roques, and K. Makasheva, "Combined effect of proteins and AgNPs on the adhesion of yeast Candida albicans on solid silica surfaces," in 2020 IEEE 20th International Conference on Nanotechnology (IEEENANO), pp. 242-245, 2020.

[9] C. Roques et al., "Consensus statement: patient safety, healthcareassociated infections and hospital environmental surfaces," Future Microbiol., vol. 10, pp. 1629-1634, 2015.

[10] T. Jinks et al., "A time for action: antimicrobial resistance needs global response,” Bull. World Health Organ., vol. 94, pp. 558-558A, 2016.

[11] M. Rai, A. Yadav, and A. Gade, "Silver nanoparticles as a new generation of antimicrobials," Biotechnol. Adv., vol. 27, pp. 76-83, 2009.

[12] B. Despax, C. Saulou, P. Raynaud, L. Datas, and M. Mercier-Bonin, "Transmission electron microscopy for elucidating the impact of silver-based treatments (ionic silver versus nanosilver-containing coating) on the model yeast Saccharomyces cerevisiae," Nanotechnology, vol. 22, p. 175101, 2011.

[13] B. Reidy, A. Haase, A. Luch, K. Dawson, and I. Lynch, "Mechanisms of Silver Nanoparticle Release, Transformation and Toxicity: A Critical Review of Current Knowledge and Recommendations for Future Studies and Applications," Materials, vol. 6, pp. 2295-2350, 2013.

[14] S. Eckhardt, P. S. Brunetto, J. Gagnon, M. Priebe, B. Giese, and K. M. Fromm, "Nanobio Silver: Its Interactions with Peptides and Bacteria, and Its Uses in Medicine," Chem. Rev., vol. 113, pp. 4708-4754, 2013.

[15] B. Le Ouay and F. Stellacci, "Antibacterial activity of silver nanoparticles: A surface science insight," Nano Today, vol. 10, pp. 339-354, 2015.

[16] A. Pugliara et al., "Assessing bio-available silver released from silver nanoparticles embedded in silica layers using the green algae Chlamydomonas reinhardtii as bio-sensors," Sci. Total Environ., vol. 565, pp. 863-871, 2016

[17] A. Pugliara, C. Bonafos, R. Carles, B. Despax, and K. Makasheva, "Controlled elaboration of large-area plasmonic substrates by plasma process," Mater. Res. Express, vol. 2, p. 065005, 2015.

[18] K. Makasheva et al., "Dielectric Engineering of Nanostructured Layers to Control the Transport of Injected Charges in Thin Dielectrics," IEEE Trans. Nanotechnol., vol. 15, pp. 839-848, 2016.

[19] A. Scarangella et al., "Adsorption properties of BSA and DsRed proteins deposited on thin $\mathrm{SiO}_{2}$ layers: optically non-absorbing versus absorbing proteins," Nanotechnology, vol. 29, p. 115101, 2018.

[20] J. A. De Feijter, J. Benjamins, and F. A. Veer, "Ellipsometry as a tool to study the adsorption behavior of synthetic and biopolymers at the air-water interface," Biopolymers, vol. 17, pp. 1759-1772, 1978.

[21] V. Nelea, Y. Nakano, and M. T. Kaartinen, "Size Distribution and Molecular Associations of Plasma Fibronectin and Fibronectin Crosslinked by Transglutaminase 2," Protein J., vol. 27, pp. 223-233, 2008.

[22] X. Wang, G. Herting, I. Odnevall Wallinder, and E. Blomberg, "Adsorption of bovine serum albumin on silver surfaces enhances the release of silver at $\mathrm{pH}$ neutral conditions," Phys. Chem. Chem. Phys., vol. 17, pp. 18524-18534, 2015.

[23] D. C. Carter and J. X. Ho, "Structure of Serum Albumin," in Advances in Protein Chemistry, vol. 45, Elsevier, 1994, pp. 153-203.

[24] C. S. Lai, C. Narasimhan, and J. J. Yin, "Evidence that the two free sulfhydryl groups of plasma fibronectin are in different local environments. Saturation-recovery electron spin resonance study," Biophys. J., vol. 56, pp. 395-400, 1989. 